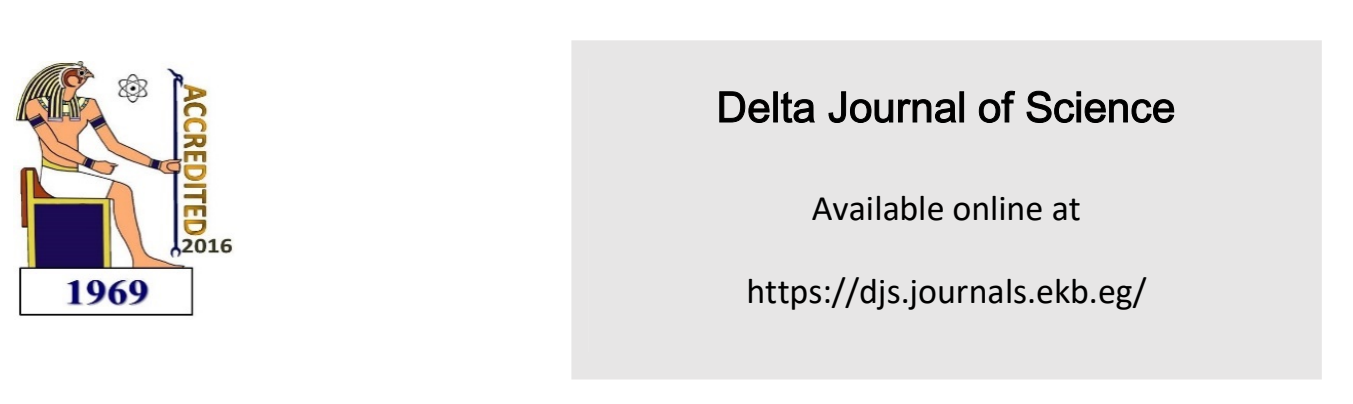

\title{
Purification and kinetic studies of bovine kidney cyclooxygenases (COXs)
}

\author{
Raef S. Shams ${ }^{1}$, Rasha Abu-Khudir ${ }^{1}$ and Ehab M. M. Ali ${ }^{1}$ \\ ${ }^{1}$ Biochemistry division, Chemistry department, Faculty of Science, Tanta University, Tanta, Egypt. \\ (Received 0 -10-2015; accepted $10-12-2015$ )
}

\begin{abstract}
Cyclooxygenases (EC 1.14.99.1) is enzyme family that produces inflammatory prostaglandins, also known as prostaglandin H synthase (PGHS) or prostaglandin-endoperoxide synthase, is expressed in several tissues. COX activity has been detected in both brain and kidney of mice and bovine kidney (that showed the highest activity). Optimum biochemical properties of enzyme activity including incubation time, enzyme and substrate concentrations and $\mathrm{pH}$ were determined. Kinetic parameters of COX activity were indicated that the $\mathrm{V}_{\max }$ and $\mathrm{K}_{\mathrm{m}}$ values were of $66.66 \mu \mathrm{mole} / \mathrm{min}$ and $125.73 \mu \mathrm{M}^{-1}$, respectively. COX has been purified from bovine kidney by detergent solubilization, $\left(\mathrm{NH}_{4}\right)_{2} \mathrm{SO}_{4}$ precipitation, dialysis and ion exchange chromatography on DEAE-sepharose. Three isoforms were obtained (coxI, coxII and coxIII) that showed specific activities of 592.27, 1323.3 and $1825 \mathrm{U} / \mathrm{mg}$ protein and $0.72,1.6$ and 2.2 folds purification over the crude homogenate, respectively. The purified enzyme exhibited a single protein band on Coomassie Brilliant Blue stained SDS-PAGE gel corresponding a molecular weight 70 KDa.
\end{abstract}

(C)2015 Delta Journal. All rights reserved.

Key words: Prostaglandins; Cyclooxygenase; Arachidonic acid; Inflammation.

\section{Introduction:}

Considering that most health conditions involve some levels of pain, it only makes sense to decipher the mechanism behind this feeling and find a means to alleviate it (Almada, 2000). These pains describe a complicated physiological process in the biological systems. Inflammation -pain potency- is a biological defense and repair mechanism of the innate immune system to protect against harmful stimuli, such as pathogens, damaged cells and tissues, toxic chemicals and irritants and thermal and mechanical stress (Jangbauer and Medjakovic, 2012). Inflammation and the balance between an inflammatory state and a normal one, antiinflammatory cytokines, such as interleukins (IL-4, IL-10, IL-13), interferon- $\alpha$ (IFN- $\alpha$ ), and transforming growth factor (TGF), that released by macrophages, could be controlled (Kanji et al., 2011). The transcription factor nuclear factor-kappa $\mathrm{B}((\mathrm{NF})-\mathrm{kB})$ regulates the expression of various genes encoding pro-inflammatory cytokines, adhesion molecules, chemokines, growth factors, chemoattractants, such as monocytes chemoattractant protein 1 (MCP-1), cyclooxygenase-2 (COX-2), and inducible nitric oxide synthase (iNOS) (Jangbauer and Medjakovic, 2012). Prostaglandins (PGs) play myriad roles as local mediators of inflammation and as modulators of physiologic functions, such as maintenance of gastric mucosal integrity, modulation of renal microvascular hemodynamics, renin release, and tubular salt and water reabsorption (Needleman et al., 1986). Although COX-2 is not expressed in the normal gastric mucosa, there has now been definitive indication for localized and regulated COX-2 expression in the mammalian kidney. The enigma concerning renal prostanoid physiology has been resolved by the identification the distribution pattern of COX-2 in the kidney (Harris et al., 1994). PGs are also now recognized as mediators of inflammatory reactions in neural tissue and more recently of brain function. Constitutive COX-2 immunoreactivity and COX-2 mRNA expression have been detected in neurons and especially in 
Raef S. Shams

the forebrain (Yamagata et al., 1993). The present study aims to purify and determine the kinetic properties of an inflammatory prostaglandin-producing enzyme (COX) that paves the way for future more inhibitory studies.

\section{Material and methods:}

\section{Materials:}

Bovine kidney was purchased from slaughter house of Tanta University, mice's brain and kidney were supplied from animal house under the ethical committee of Faculty of Science of Tanta University, Arachidonic acid was purchased from Cayaman chemical co., N,N,N',N'tetramethyl-p-phenylenediamine (TMPD) and Tween 40 were purchased from Acros organics co., Hematin and DEAE-sepharose were purchased from Sigma chemicals co., All of the chemicals were of high grade.

\section{Methods:}

\section{Preparation of crude homogenates from tissues of interest}

Preparation of $20 \%$ crude homogenate of mice kidney and brain and bovine kidney in $0.1 \mathrm{M}$ Tris- $\mathrm{HCl}$ buffer pH8.0 was carried on in a blender at full speed at room temperature for $5 \mathrm{~min}$. After centrifugation at $10.000 \mathrm{x} \mathrm{g}$ at $4^{\circ} \mathrm{C}$ for $15 \mathrm{~min}$, the microsomal pellet and Tween 40 (2:1) $(\mathrm{v} / \mathrm{v})$ were suspended in the same buffer containing $1 \mathrm{mM}$ EDTA. The suspension was subjected to centrifugation for $1 \mathrm{~h}$ at $60.000 \mathrm{x} \mathrm{g}$ at $4^{\circ} \mathrm{C}$ and the supernatant was assayed for enzyme activity (Madhava et al, 2000).

\section{Screening of COXs activity}

The enzyme activity was assayed colorimetrically by monitoring the appearance of oxidized N,N,N',N'tetramethyl-p-phenylenediamine (TMPD) at $600 \mathrm{~nm}$ (Copeland et al., (1994) ; Petrovic and Murray, 2010). The assay mixture contained Tris- $\mathrm{HCl}$ buffer $(0.1 \mathrm{M}, \mathrm{pH}$ $8)$, Hematin $(60 \mu \mathrm{M})$, EDTA $(3 \mu \mathrm{M})$ and enzyme $(10 \%$ of total volume). The mixture was incubated for 10 minutes at $25{ }^{\circ} \mathrm{C}$ and then, the reaction was initiated by the addition of arachidonic acid $(200 \mu \mathrm{M})$ and TMPD (3.3 $\mathrm{mM}$ ) in a total volume of $1 \mathrm{ml}$. The blank was assembled by subjecting inactive enzyme (boiled fractions) instead of active one. The activity calculated from the following equation:

$$
\text { Activity }=\frac{\Delta \mathrm{A}_{600} / 10 \mathrm{~min}}{0.00826 \mu \mathrm{M}^{-1}} \times \frac{\text { Assay volume }}{\text { Enzyme volume }} \div 2=\mathrm{U} / \mathrm{ml}
$$

\section{Protein Determination}

Protein concentration was determined either by measuring the absorbance at $280 \mathrm{~nm}$ (Warburg and Christian, 1941) or according to the protein dye-binding Bradford assay (Bradford, 1976) using bovine serum albumin (BSA) as a standard.

\section{Purification of Cyclooxygenase}

All steps were performed under cold condition in a 0.1 M Tris-HCl pH 8.0 (Hemler and Lands, 1976).
Ammonium sulphate precipitation of $20 \%$ crude homogenate was performed gradually by $25 \%$ then $54 \%$ ammonium sulphate saturation. Powdered (NH4)2SO4 was added gradually with stirring to the crude homogenate till reach $25 \%$ saturation. Subsequently, the homogenate was centrifuged at $24000 \mathrm{x}$ g for $20 \mathrm{~min}$. The supernatant was carefully decanted and the pellet was resuspended in $20 \mathrm{ml}$ of Tris- $\mathrm{HCl}$ (0.1M, pH 8.0) and recentrifuged. Combined supernatants were brought to $54 \%$ saturation by drop wise addition of saturated ammonium sulfate solution in the same buffer. The suspension was centrifuged at $24000 \mathrm{x} \mathrm{g}$ for $30 \mathrm{~min}$, the supernatant was removed and the pellet was saved for desalting by dialysis.

Dialysis was performed to remove the excess of ammonium sulphate bound to protein. The sample was dialyzed overnight against Tris- $\mathrm{HCl}(0.1 \mathrm{M}, \mathrm{pH} 8.0)$ in a dialysis bag with a molecular weight cut-off (MW CO) diameter of 12000 Daltons. The buffer was exchanged several times to ensure that the pellet became free of ions. Thereafter, the dialyzed pellet was centrifuged at $6000 \mathrm{x} \mathrm{g}$ and the filtrate was kept for further chromatographic purification techniques.

DEAE- sepharose column chromatography of desalted protein fraction $(2 \mathrm{ml})$ that was applied to anionic exchange of DEAE-sepharose $(7 \times 2 \mathrm{~cm}$ i.d. column $)$ that was previously equilibrated with Tris- $\mathrm{HCl}$ buffer $(0.05 \mathrm{M}$, $\mathrm{pH}$ 8.0). Elution was carried out with Tris- $\mathrm{HCl}$ buffer (0.05 M, pH 8.0) followed by a gradient of $\mathrm{NaCl}(0.1-0.5$ $\mathrm{M})$ in the same buffer and fractions were collected (3 $\mathrm{ml} /$ $5 \mathrm{~min}$ ). The absorbance of every tube was measured at 280 $\mathrm{nm}$ and the enzyme assay was carried out in proteincontaining tubes.

SDS Polyacrlamide Gel Electrophoresis under denaturing conditions, SDS-PAGE was performed on 10 $\%(\mathrm{w} / \mathrm{v})$ acrylamide slab gel according to the basic approach of (Laemmli, 1970 ; Goswami et al., 2003) using a Tris-glycine buffer $\mathrm{pH}$ 8.3. The slab gel was carried out using CLEVER SCIENTIFIC Omni PAGE Mini System at $100 \mathrm{~V}$ per slap gel. Samples of $20 \mu \mathrm{l}$ containing $8 \mu \mathrm{g}$ proteins were applied to the wells of stacking gel. Electrophoresis was carried out until the bromophenol blue marker reached the bottom of the gel. Subsequently, the gel was subjected to coomassie staining for overnight then soaked in destaining solution for overnight with shaking until the bands were properly seen. The approximate molecular weight of the visualized protein bands was determined by comparing them with the molecular weight ladder (protein marker).

\section{Kinetic Studies of Cyclooxygenase}

The effect of time, enzyme concentration, substrate concentration and different $\mathrm{pH}$ values of reaction on COXs catalytic activity was tested.

Effect of time: Enzyme assay - as previously described was carried out at different time points ranging from 5 to $40 \mathrm{~min}$.

Effect of enzyme concentration: Enzyme assay was carried out using different enzyme concentrations 0.41 , $0.82,1.23,1.64$ and $2 \mu \mathrm{g} / \mathrm{ml}$. 
Raef S. Shams

Effect of substrate (Arachidonic acid) concentration: The effect of substrate concentrations in the range 50 to $500 \mu \mathrm{M}$ were on enzyme activity was investigated.

Michael's constant $\left(\mathbf{K}_{\mathbf{m}}\right.$ value): The kinetic parameter, $\mathrm{K}_{\mathrm{m}}$, indicates the affinity of cyclooxygenase towards its substrate, Arachidonic acid. It was determined using the Lineweaver-Burk reciprocal plot graphic method.

Optimum pH: Different buffer systems of $\mathrm{pH}$ values between 3.8 and 11 were assembled to detect the optimum $\mathrm{pH}$ of the enzyme.

\section{Results and discussion:}

Cyclooxygenase, a key enzyme involved in the biosynthesis of prostaglandin (smith et al., 1996). It plays an important role in inflammation and variety of other disorders (Cummings et al., 1977). With the discovery of inducible form of cyclooxygenase, COX-2 (Xie et al, 1991), it has been postulated that PGs, which contribute to inflammatory process, are derived exclusively from COX2 , on the other hand, many of the "house-keeping" effects of COX appear to be mediated by COX-I (Madhava et al., 2000).

In the present study, we evaluated the expression of cyclooxygenase in different tissues isolated from different animals (Table 1). The results showed that the screened activity of the mice kidney $(40.78 \mathrm{U} / \mathrm{ml})$ was higher than that of mice brain $(24.8 \mathrm{U} / \mathrm{ml})$. Comparatively, the activity of bovine kidney COX, was the highest $(54.14 \mathrm{U} / \mathrm{ml})$ in the crude homogenate with a specific activity of $(826.95$ $\mathrm{U} / \mathrm{mg}$ protein). Rome and Lands showed that COX has been expressed in sheep seminal vesicles with a 60 -fold purification following solubilization; however bovine seminal vesicle showed only 10 -fold purification after solubilization (Miyamoto et al., 1974). On the other hands, COX expression in the kidneys of rabbits exhibited a specific activity of $3.12 \times 10^{-3} \mu \mathrm{mole} / \mathrm{min} / \mathrm{mg}$ protein $(\mathbf{W u}$ Yu Sheng et al., 1982)

COX purification has been improved by starting with ammonium sulphate precipitation that helped to concentrate the crude homogenate before introducing to dialysis. The dialyzed materials were applied to a DEAEsepharose column that resolved the enzyme into three different isoforms designated as coxI, coxII and coxIII (Fig 1). Quantitative comparisons of the enzyme activity at different stages of purification are shown in (Table 2). Closely related purified isoforms, coxI, coxII and coxIII, showed different percentage of recovery as 13.4, 11.2 and 10.3 with increasing in specific activities as 592.27, 1323.3 and $1825 \mathrm{U} / \mathrm{mg}$ protein, respectively. Other study showed that the highest enzyme activity had been detected in seminal vesicles with a specific activity of $(11600 \mathrm{U} / \mathrm{mg}$ protein) in the DEAE-cellulose eluant that also represented
$10 \%$ recovery from the crude homogenate (Hemler and Lands, 1976).

SDS-polyacrylamide gel electrophoresis was performed on enzyme fractions - considered three different isoforms after DEAE-sepharose chromatography, for each fraction, a single band appeared within a range of $68-70 \mathrm{KDa}$ (Fig 2 ), while a single band of $72 \mathrm{KDa}$ was reported in the case of UV induced human COX-2 (Zhang et al., 2006). Likewise, recombinant human COX-1 and COX-2 assumed a molecular mass of $70 \mathrm{KDa}$ (Vezaa et al., 1996).

Enzyme assay was carried out repeatedly at different conditions to determine the optimum ones. In this context, when different time periods were applied in the enzyme assay, it showed that activity increased from zero time till it reached its maximum after $20 \mathrm{~min}$. beyond this, the enzyme activity remained constant as time increases (Fig 3). Different enzyme (COX) and substrate (arachidonic acid) concentrations under other stable assay conditions showed increasing enzyme activity directly (Fig 4 and 5, respectively). The affinity of $\mathrm{COX}$ towards arachidonic acid (Michaelis-Menten constant $\left(\mathrm{K}_{\mathrm{m}}\right)$ ) was determined and showed a value of $125.73 \mu \mathrm{M}$. The linear nature of Line weaver-Burk plots Shows that the maximum reaction velocity $\left(\mathrm{V}_{\max }\right)$ value is $66.66 \mu$ mole product $/$ minute $/ \mathrm{ml}$ (Fig 6) (Lineweaver and Burk, 1934). Sheng and his colleagues indicated that the $\mathrm{K}_{\mathrm{m}}$ value for the enzymatic conversion of arachidonate to $\mathrm{PGE}_{2}$ in rabbit's kidney was $10-20 \mu \mathrm{M}$ with a $\mathrm{V}_{\max }$ of $3.44 \times 10^{-3} \mu \mathrm{mole} / \mathrm{mg}$ protein $/ \mathrm{min}$ that determined at $80 \mu \mathrm{M}$ arachidonic acid. Optimum $\mathrm{pH}$ was identified by assaying the enzyme activity over a wide range of $\mathrm{pH}$. The highest activity was recorded by Tris$\mathrm{HCl}$ buffer, $\mathrm{pH} 8.0$ (Fig 7). However, in a previous study the highest activity of COX was reported in $0.1 \mathrm{M}$ phosphate buffer, pH 7.8 (Riengold, 1981).

\section{Conclusion:}

Three different isozymes of cyclooxygenase COXI, COXII and COXIII with a molecular weight of $70 \mathrm{KDa}$, were observed in purification folds from DEAE-sepharose column chromatography with $0.72,1.6$ and 2.2 fold purification over the crude one, respectively. $\mathrm{K}_{\mathrm{m}}$ value of 125.73 $\mu \mathrm{M}$ and $\mathrm{V}_{\max }$ value of $66.66 \mu$ mole product $/$ minute $/ \mathrm{ml}$ were determined.

Table (1): COXs activity in different organs of different animals.

\begin{tabular}{cc}
\hline Animal/ Organ & Activity (U/ml) \\
\hline Mice brain & 24.8 \\
Mice kidney & 40.78 \\
Bovine kidney & 54.14 \\
\hline
\end{tabular}




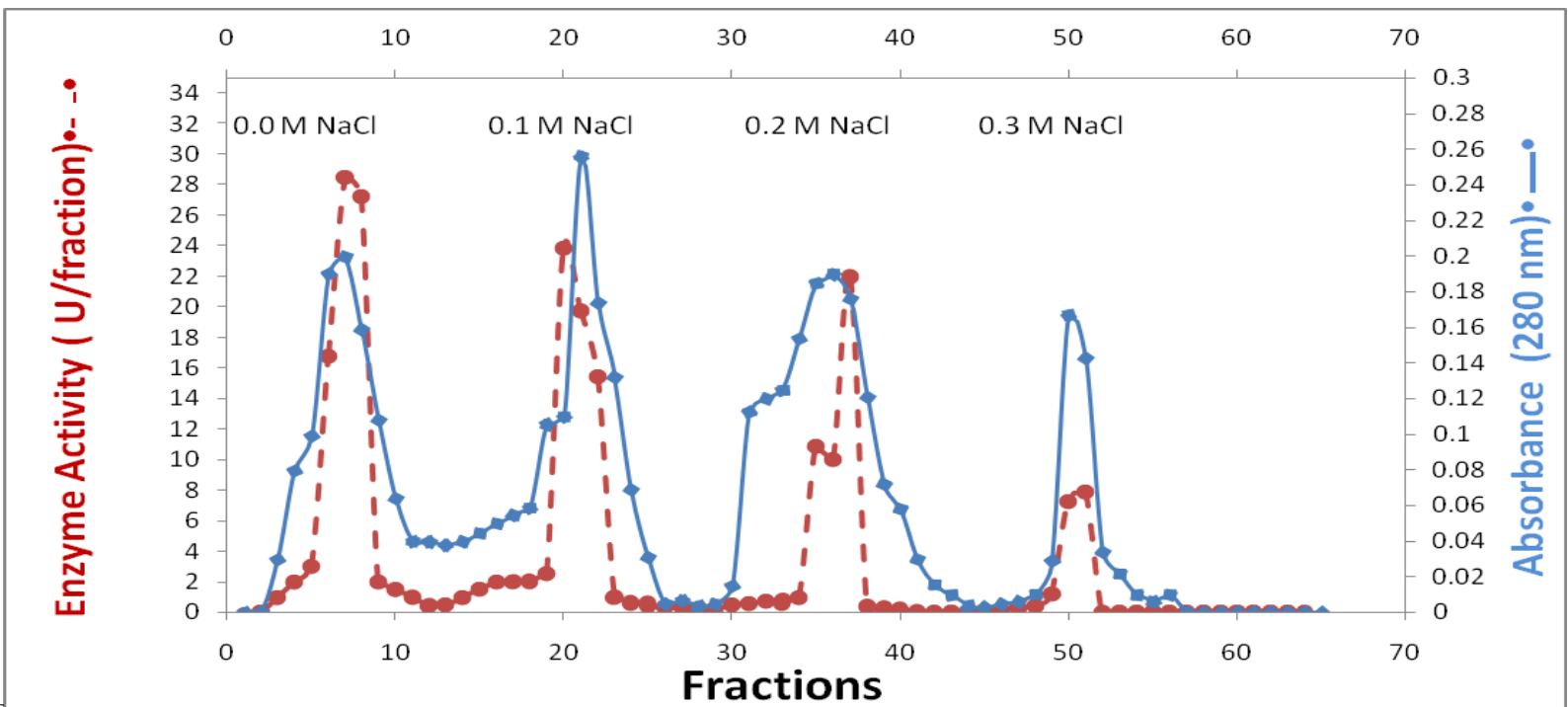

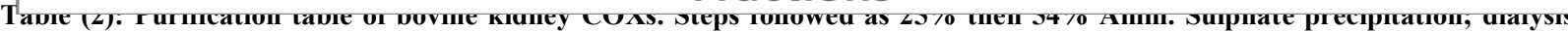
and column chromatography on DEAE-sepharose with gradient $\mathrm{NaCl}$ buffers.

\begin{tabular}{|c|c|c|c|c|c|}
\hline Step & $\begin{array}{c}\text { Total protein } \\
(\mu \mathrm{g})\end{array}$ & $\begin{array}{c}\text { Total activity } \\
\text { (Units) }\end{array}$ & $\begin{array}{l}\text { Specific activity } \\
\text { (U/mg protein) }\end{array}$ & $\begin{array}{c}\text { Recovery } \\
(\%)\end{array}$ & $\begin{array}{c}\text { Fold } \\
\text { purification }\end{array}$ \\
\hline Crude homogenate (20\%) & 1028.8 & 850 & 826.85 & 100 & 1 \\
\hline \multicolumn{6}{|l|}{$\left(\mathrm{NH}_{4}\right)_{2} \mathrm{SO}_{4}$ precipitation: } \\
\hline $25 \%$ fold & 201.6 & 225.44 & 1118.25 & 26.52 & 1.35 \\
\hline $54 \%$ fold & 253.4 & 174.7 & 689.42 & 20.55 & 0.83 \\
\hline Combined folds & 454.86 & 410.94 & 903.44 & 48.34 & 1.1 \\
\hline Dialysis of combined folds & 391.2 & 257.55 & 658.35 & 30.3 & 0.8 \\
\hline \multicolumn{6}{|l|}{ DEAE Sepharose: } \\
\hline $\operatorname{coxl}(0.0 \mathrm{M} \mathrm{NaCl})$ & 192.48 & 114 & 592.27 & 13.4 & 0.72 \\
\hline coxll (0.1 M NaCl) & 72 & 95.28 & 1323.3 & 11.2 & 1.6 \\
\hline $\operatorname{coxIII}(0.2 \mathrm{M} \mathrm{NaCl})$ & 48 & 87.6 & 1825 & 10.3 & 2.2 \\
\hline
\end{tabular}

Figure (1): Elution profile of bovine kidney COXs through DEAE-sepharose column (7x2 cm) equilibrated with 0.05M Tris-HCI buffer $\mathrm{pH} 8.0$ with flow rate $3 \mathrm{ml} / 5 \mathrm{~min}$.

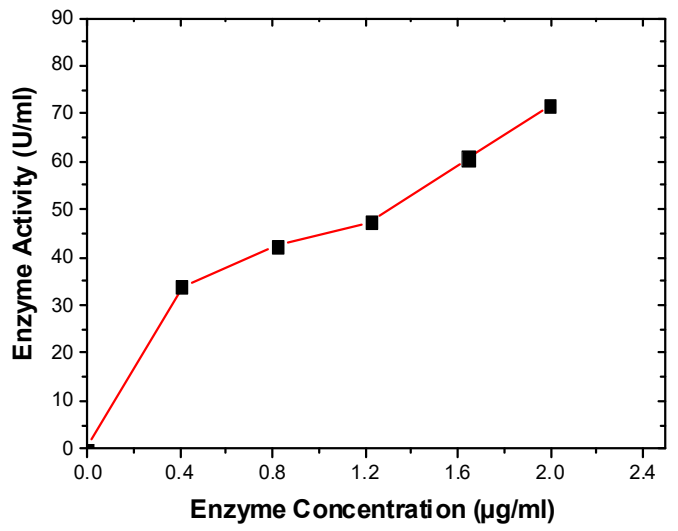




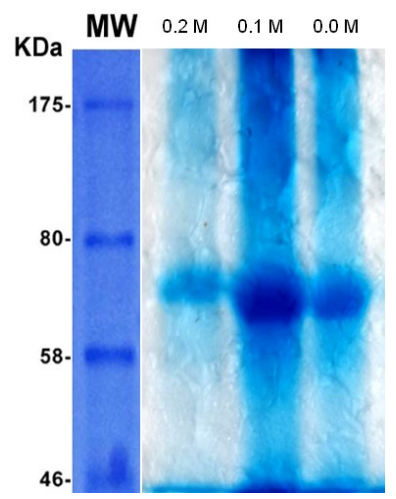

Figure (2): SDS-PAGE of purified bovine kidney COXs fractions on $10 \%$ acrylamid gel at $100 \mathrm{~V}$ per slap showing three different isozymes of nearby molecular weights.

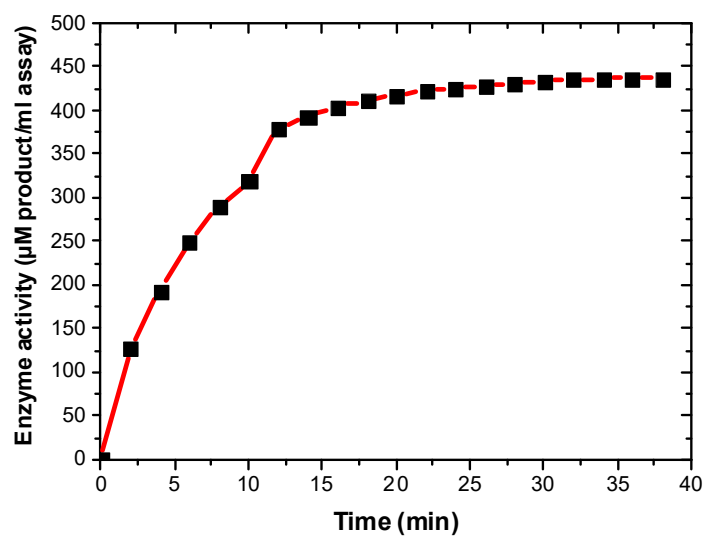

Figure (3): Effect of time on bovine kidney COXs activity showing increasing in activity by the time till reaction reach maximum.

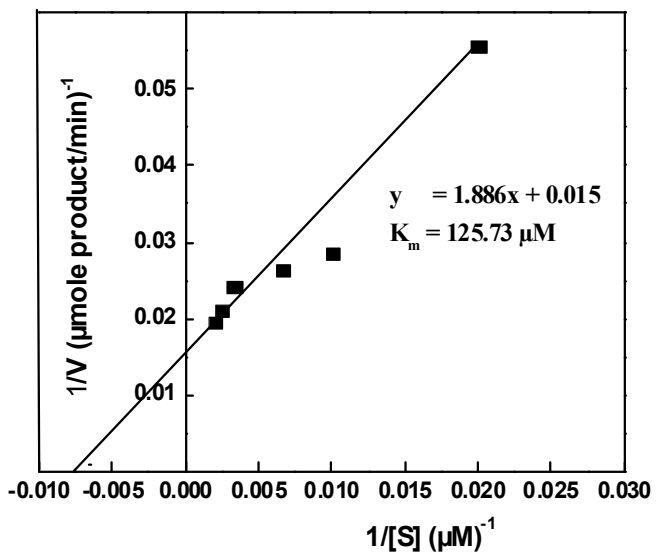

Figure (6): Linweaver-Burk plot of COXs reaction velocity to Arachidonic acid concentration.

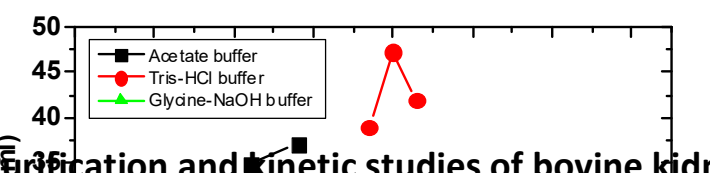

Figure (4): Effect of enzyme concentration on bovine kidney COXs activity showing increasing activity by increasing enzyme concentration.

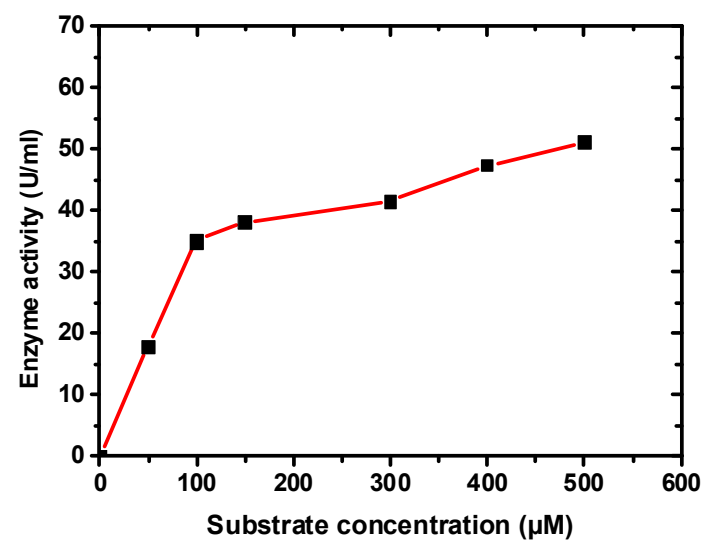

Figure (5): Effect of substrate concentration on bovine kidney COXs activity showing increasing activity by increasing substrate that shows slightly stability.

Harris RC, McKanna JA, Akai Y, Jacobson HR, Dubois RN, Breyer MD (1994) Cyclooxygenase-2 is associated with the maculadensa of rat kidney and increases with salt restriction. J Clin Invest 94: 2504 2510 .

Jangbauer A. and Medjakovic S. (2012): Anti-inflammatory properties of culinary herbs and spices that ameliorate the effects of metabolic syndrome, Maturitas 71227 : 239.

Joan Clària (2003): Cyclooxygenase-2 Biology, Current Pharmaceutical Design, 9, 2177-2190.

Laemmli, U.K. (1970): Cleavage of structural proteins during the assembly of the head of bacteriophage T4. Nature, 227(5259):680-685.

Lineweaver H. and Burk D. (1934): The Determination of Enzyme Dissociation Constants". Journal of the American Chemical Society 56 (3): 658-666.

M Hemler and W E Lands (1976): Purification of the 
cyclooxygenase that forms prostaglandinsDemonstration of two forms of iron in the holoenzyme. J. Biol. Chem. 251:5575-5579.

Madhava Reddy, Vadiraja B. Bhat, G. Kiranmai, M. Narsa Reddy, P. Reddanna, and K. M. Madyasthat (2000): Selective lnhibition of Cyclooxygenase-2 by CPhycocyanin, a Biliprotein from Spirulina platensis, Biochemical and Biophysical Research Communications 27 7, 599 - 603 .

Miyamoto, T., Yamamoto, S., and Hayaishi, (1974): Prostaglandin synthetase system--resolution into oxygenase and isomerase components.Proc Natl.Acad. Sci. U. S. A. 71, 3645-3648

Figure (7): Effect of different buffers with different $\mathrm{pH}$ on bovine kidney COXs activity that shows optimum pH in TRIS-HCl system.

\section{References:}

Almada A. (2000): Natural COX-2 inhibitors: The future of pain relief, Nutrition science news.

Bradford M. (1976): A rapid and sensitive method for the quantification of microgram quantities of protein utilizing the principle of dye binding.Analyt.Biochem.72: 248-254.

Copeland, R. A., Williams, J. M., Giannaras, J., Nurnberg, S., Covington, M., Pinto, D., Pick, S., and Trzaskos, J. M. (1994): Mechanism of selective inhibition of the inducible isoform of prostaglandin G/H synthase. Proc. Natl. Acad. Sci. USAgl, 11202-11206.

Cummings, K. B., and Robertson, R. P. (1977): Prostaglandin: increased production by renal cell carcinoma. J. Urol. fia, 720-723.

Goswami, K., Nandakumar, D.N., Koner, B.C., Bobby, Z. and Sen, S.K. (2003): Oxidative changes and desialylation of serum proteins in hyperthyroidism. Clin Chim Acta. 337(1-2):163-168.

Smith, W. L., Garavito, R. M., and DeWitt, D. L. (1996): J. Biol. Chem. 27 1, 331 57-33160.

Turner JJ, Foxwell KM, Kanji R, et al. (2011): Investigation of nuclear factor-kappaB inhibitors and interleukin-10 as regulators of inflammatory signalling in human adipocytes. Clin Exp Immunol; 162:487-93.

Warburg, O. and W. Christian (1942): Isolation and crystallization of enolase. Biochem. Z. 310:384-421.

Wu Yu Sheng, Angela Wyche, Thomas Lysz, and Philip Needleman (1982): Prostaglandin Endoperoxide E2 Isomerase Is Dissociated from Prostaglandin Endoperoxide Synthetase in the Renal Cortex, The Journal of biological chemistry, Vol. 257, No. 24, Issue of December 25, pp. 14632-14634.

Xie, W. L., Chipman, J. G., Robertson, D. L., Erikson, R. L., and Simmons, D. L. (1991): Expression of a mitogen-responsive gene encoding prostaglandin synthase is regulated by mRNA splicing.Proc. NatI. Acad. Sci U5A88, 2692-2696.

Yamagata K, Andreasson KI, Kaufman WE, Barnes CA
Needleman P, Turk J, Jakschik BA, Morrison AR, Lefkowith JB (1986): Arachidonic acid metabolism. Annu Rev Biochem 55: 69-102.

Petrovic N. and Murray M. (2010): Using N,N,N,N tetramethyl-p phenylenediamine (TMPD) to Assay Cyclooxygenase Activity In Vitro. Advanced protocols in oxidative stress; 594: 129-140.

Qiwei Zhang, Holger Seltmann, Christos C. Zouboulis and Raymond L. Konger (2006): Involvement of PPARc in Oxidative Stress-Mediated Prostaglandin E2 Production in SZ95 Human Sebaceous Gland Cells. Journal of Investigative Dermatology 126, 42-48.

Reingold, D. F., Watters, K., Holmberg, S., and Needleman, P. (1981): Differential biosynthesis of prostaglandins by hydronephrotic rabbit and cat kidneys. J. Pharmacol. Exp. Ther. 215, 510-515.

Roberta Vezza, Aıda Habib, Hongwei Li, John A. Lawson, and Garret A. FitzGerald (1996): Regulation of Cyclooxygenases by Protein Kinase C. THE JOURNAL OF BIOLOGICAL CHEMISTRY, Vol 271, No. 47, Issue of November 22, pp. 30028-30033.

Rome, L. H., and Lands, W. E. M. (1975): Properties of a partially-purified preparation of the prostaglandinforming oxygenase from sheep vesicular gland. Prostaplandins 10.813-824.

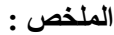

تقوم العليد من الأنسجة بتكوين إنزيمات السيكلو أوكسجنيز ذات الرقم

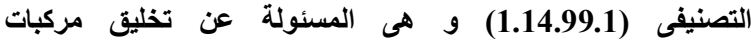

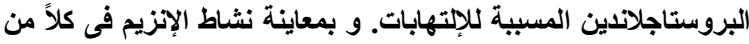

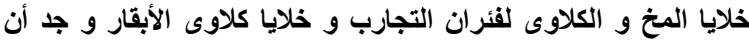

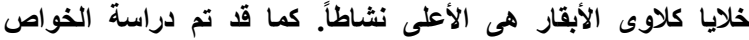

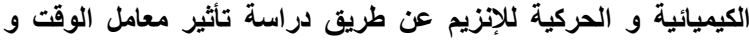

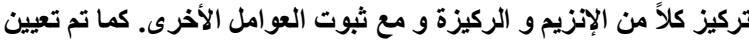

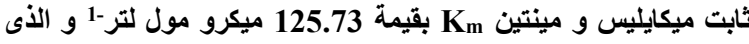

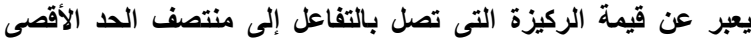
لقئ

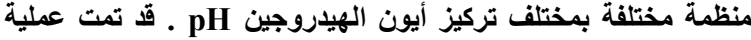

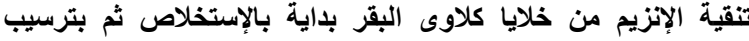

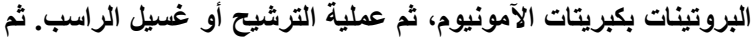
عملية الفصل الكروماتوجرافى العمودي على مادة الداى إيثيل أمينو إيثيل

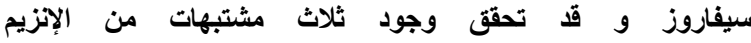
تشاط بنشاط COXIII،COXII،COXI نشاط لكل مجم بروتين ما يمثل 0.72، 1.6، 2.2 ضعفاً من النقاوة عن 


\section{Raef S. Shams}

(1993): Expression of a mitogen-inducible cyclooxygenase in brain neurons: regulation by synaptic activity and glucocorticoids. Neuron; 11: 371386.
المستخلص الخام، على الترتيب. و بقياس الوزن الجزيئى للمشتبهات الثلاثة وجد أنهم على نفس الوزن 70 كيلو دالتون. 